\title{
Interactive comment on "On the information content in linear horizontal delay gradients estimated from space geodesy observations" by Gunnar Elgered et al.
}

\section{Gunnar Elgered et al.}

gunnar.elgered@chalmers.se

Received and published: 22 February 2019

The comment was uploaded in the form of a supplement:

https://www.atmos-meas-tech-discuss.net/amt-2018-318/amt-2018-318-AC1-

supplement.pdf

Interactive comment on Atmos. Meas. Tech. Discuss., doi:10.5194/amt-2018-318, 2018. 